\title{
Cultural Dissemination: A Case Study of English Text Books at Primary Level in Pakistan
}

\author{
Shazia Dar ${ }^{1}$, Farzana Masroor $^{2}$
}

\begin{abstract}
Textbooks act as an embodiment of education policy and carry great significance in classroom teaching. The content of these discourses reflects the existing cultural, religious or social norms of a country and acts as a means to exercise power of the dominant groups. The present investigation focuses to unmask prevalent cultural and social ideologies in the literary discourses of Pakistani English primary textbooks of the four provinces (Punjab, Sindh, Baluchistan and Khyber Pakhtunkhwa). The analysis pertains to two levels: content analysis to quantify cultural themes and discourse analysis to validate the results and gain insight into the data by using three-dimensional Critical Discourse Analysis framework by Norman Fairclough. The findings of the study highlight significant disproportion of cultural representations in the data. The results reflect embodiment of dominant provincial ideologies and advocate a revision of curriculum and education policy for serving wider educational needs in the local and international context.
\end{abstract}

Keywords: Cultural messages, Ideology, English Textbooks, Primary Education

\section{Introduction}

The research in linguistics explores language use through insights from multiple fields such as psychology, anthropology and sociology. However, the interests of critical discourse analysts lie in scrutinizing language use for the exercise of power by the dominant groups and ways of resistance (Simpson \& Mayer, 2010). The current investigation is interested in intersection of language and social and political reflexes of power (Simpson \& Mayer, 2010) in the data of English provincial textbooks by uncovering the ideological perspectives and power relations in the curriculum.

Textbooks being important classroom educational tools heavily influence social, mental and cultural growth of the students (Kemp, 1977 as cited in Beiki $\&$ Gharaguzlu, 2017). The four main ingredients of educational context include

\footnotetext{
${ }^{1} \mathrm{PhD}$ scholar, Department of English Linguistics, Air University Islamabad Email: shazia.rd@gmail.com

${ }^{2}$ Assistant Professor, Department of English Linguistics, Air University Islamabad Email: farzanamasroor@hotmail.com
} 
textbooks, learners, teachers and the context itself (Razmjoo \& Jozaghi, 2010). Furthermore, textbooks as teachers' tools provide learning and teaching context and circumstance (Beiki \& Gharaguzlu, 2017).

Being an integral part of education policy of any country (Weninger \& Kiss, 2013) the content of textbooks reflects and maintains its existing cultural, religious or social norms and values of the powerful groups (Su, 2007). In Pakistani context, more than 70 languages are spoken but people refrain from adopting a fixed national identity. The idea of provincialism has a stronghold and regional languages serve to strengthen ethnic identities and power struggle with textbooks used to interpret Islamic teachings used as a support for nationalism with militarisms being the most desired value (Rehman, 1995; 2003). This study is an innovative attempt to explore whether the curriculum reflects unity among the provinces or the reproduction of the beliefs of autonomous bodies.

\subsection{Objective of Study}

This study intends to explore what cultural contents/messages along with the existence of national and target cultural elements are presented in the primary textbooks of four provinces.

\subsection{Research Questions}

The researcher aims to investigate,

1. Which cultures (national, ethnic \& target) are disseminated in the primary textbooks of the four provinces of Pakistan?

2. How these cultural representations (regional, national and international) are made?

3. How power relations are inscribed in the textbooks?

\subsection{Delimitation of Study}

This study is delimited to only four Pakistani provincial textbooks of English at primary level, excluding other teaching materials and curriculum items. The method of analysis is delimited to content and text analysis based on research goals.

\section{Literature Review}

Halliday's notion of functional linguistics (1973) emphasizes the role of culture and its impact on English language learners' competence (as cited in Ping, 2011). Along with imparting information (Gee, 2014), culture also predetermines our world view and vision to perceive reality (Edward Sapir in Lyons, 2011). This inculcates that language and culture are tied together. Three types of culture through which the cultural elements in the English textbooks could be explored (Cortazzi \& Jin, 1999 as cited in Kirkgoz \& Agcam, 2011) include source culture (learner's own culture), target culture (target language 
spoken as first language or mother tongue) and international target culture in English or non-English speaking countries which use English as an international language (as cited in Hermawan \& Noerkhasanah, 2012).

Discourse usually means language in use, that is, how people act, interact, feel, and think in a context (Gee, 2000). Gee's agrees with Michel Foucault's (1977) in viewing discourse that considers language as embodiment of knowledge and power (Rogers, Malancharuvil-Berkes, Mosley, Hui \& Joseph, 2005). Foucault's approach towards discourse as a means to transmit and produce power (1998) has been utilized in many of educational debates and policies to uncover how educational discourses including textbooks serve as a tool to exercise power for the powerful groups. Language serves as a vehicle for the exercise of power (Corson, 1995; Bourdieu, 1977) as well as an instrument for deconstructing dominant discourse (as cited in Pitsoe \& Letseka, 2013). The interconnectedness of language and the social structures (Wodak, 2002) entails discourse as a kind of social action/power (van Dijk, 2001) that is "socially constitutive" and "socially determined" (Fairclough, 1996; 2015).

The notion of power as force or coercive power is graspable (Ball \& Goodson, 2007), but power through consent (see Gramsci's 'ideological hegemony') is difficult to understand. The education system is governed by official discourses reflective of educational policies, such as in curriculum development, school management and assessment system etc. (Ball \& Goodson, 2007). Hence, curriculum becomes an ideological instrument through which the educational system practices its hegemony upon the students through its bureaucratic beliefs and norms as reflected in textbooks' contents and objectives, thus making a pertinent case for conducting this research.

In alignment with social and critical theorists, Apple $(1996 ; 2004)$ emphasizes the role of educational institutes as platforms of control on economic and cultural sources. Thus far from being neutral mediums, curriculum acts as a place for reflection of prevalent ideologies (as cited in Ping, 2011). Therefore, analysis of school textbooks and curriculum can reveal hidden patterns through which certain themes were being included or excluded (Beiki \& Gharaguzlu, 2017; Su, 2007).

English teaching and learning materials, textbooks in this case, cover hidden patterns that comprises certain values and ideology built into materials by design, such as attitudes toward knowledge, teaching and learning, role and relationship of the teacher and students, and values and attitudes related to gender, society etc. (Hermawan \& Noerkhasanah, 2012). Therefore, the uncritical views about loyalty and commitment are achieved through national glorification (as cited in Ping, 2011). In Malaysian context, a need for dissemination of local 
culture in English textbooks is observed (Abdullah, 2009), while little benefit is observed through integration of western culture in Moroccan textbooks (Adaskou, Britten \& Fahsi, 1990), which resulted in the tendency of comparison among the learners with their own culture. Contrarily, Suemasa (2004) believes this as an important way of raising awareness of both cultures. In Taiwanese context, $\mathrm{Su}$ (2007) investigated the ideological representation in the primary level textbooks for the reflection of ethnic and political connections, nationalism, state's achievements and legitimization of women's experiences. The competing ideologies reflected in textbooks of Republic of China were observed to be the epitome of established discursive systems (You, 2005). The element of target culture, however, in Iranian context was dominated by local culture and ethnic values in EFL textbooks (Dehbozorgi, Amalsaleh \& Kafipour, 2017). Considering these researches, this research aims to analyze the discursive cultural representation in English textbooks of Pakistan at the provincial level.

\section{Research Methodology}

\subsection{Research Design}

The study undertakes the analysis of textbook genre by making use of content analysis and discourse analysis. Mixed method approach involves both qualitative and quantitative data and use of distinct designs which incorporates theoretical frameworks and philosophical assumptions (Creswell, 2016) as well as practical procedures to allow a complete understanding of research problems. Content analysis refers to the study of larger ideas, issues and themes in the discourse, by linking them to broader social context in order to find historical connections and powerful structures of the text under observation (Stevens, 2016). In this study content analysis generated four general categories coded further into nine sub-categories on the basis of themes of the textbooks' units (Krippendorff, 1980).

The text analysis level adheres to critical discourse analysis (CDA) through three dimensional model of Norman Fairclough (2015). For the textual analysis, extracts were selected from the textbooks under the general categories of national, religious, regional and international. Furthermore, the linguistic properties of Description stage are symbolism, metaphor, allegory, presupposition and implicature. The Interpretation stage helps to grasp what is in text and also explores the background knowledge. In the third stage of Explanation, the selected extracts have been viewed in the broader contexts of social structures. The model was particularly used to focus on the comparison of source and target culture elements. Figure 1 shows procedure of data analysis. 


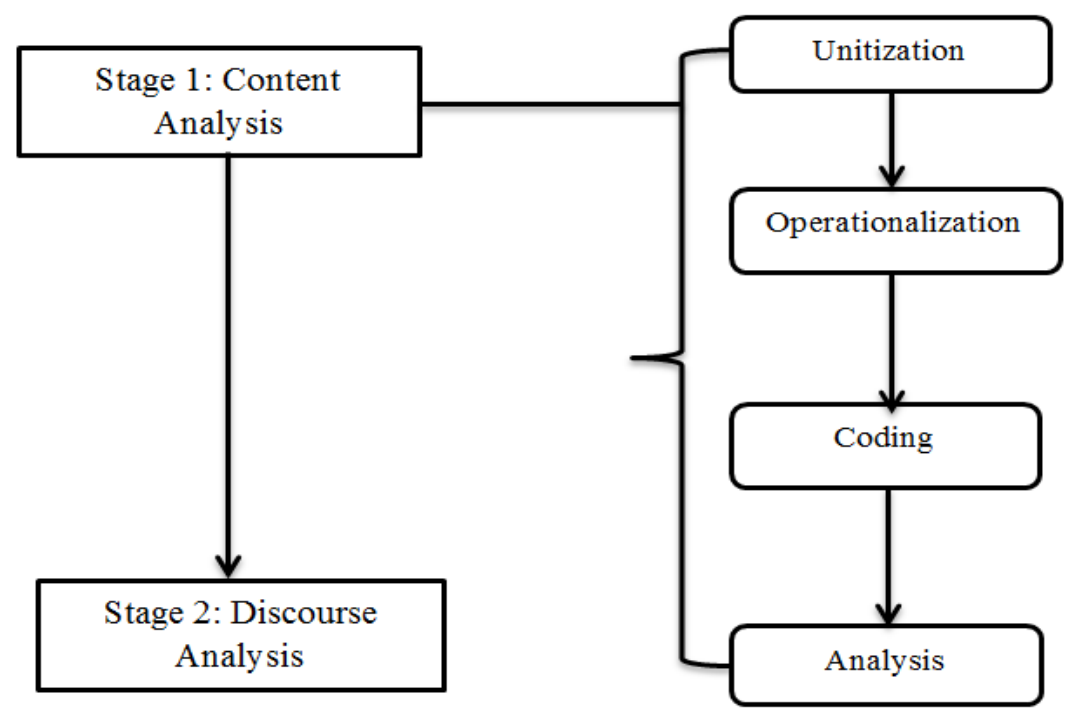

Figure 1. Data analysis process

The definitions of both the general and specific categories are given in the Tables 1 and 2, coded according to the themes of the present research.

Table 1

Definitions of general categories

\begin{tabular}{ll}
\hline Categories & Definitions \\
\hline National & $\begin{array}{l}\text { Implicit \& explicit information about country or nation, its } \\
\text { culture and norms, territorial knowledge or natural }\end{array}$ \\
& $\begin{array}{l}\text { landscapes } \\
\text { Regional }\end{array}$ \\
Knowledge about regional customs, festivals \& sports \\
Religious & $\begin{array}{l}\text { Information about any religion or religious norms and } \\
\text { values }\end{array}$ \\
International & Information about the target culture \\
\hline
\end{tabular}


Table 2

Definitions of Sub-categories

Categories

Definitions

Beliefs (BE)

Implicit \& explicit information on Islamic beliefs and rituals

Customs \& Values

(CV)

Cultural knowledge about customs, festivals \& national sports

People \& Achievements Knowledge about historical figures or role models;

(PA)

Information about any national achievements

Activities (ACT)

Science (SCI) Information about any leisure or household activities

Education (EDU)

Teacher's role (TR) Knowledge for any scientific activity \& invention Information on education systems particularly on female education

Geography (GEO) Implicit knowledge about the authoritative role of a teacher

Territorial knowledge, such as, any information about the city or place in Pakistan

Natural Resources (NR) Understating about landscapes

\subsection{Sample and Sampling Technique}

Four English textbooks of $5^{\text {th }}$ grade, used in Pakistani government schools of the four provinces (Punjab: Punjab Primary Textbook of English; Baluchistan: English Language Grade 5; Sindh: My English Book and Khyber Pakhtunkhwa: My English Reader) were selected by purposive sampling for exploring hidden ideologies.

\section{Data Analysis \& Interpretation}

The analysis presents descriptive statistical results of the content analysis, followed by discourse analysis.

\subsection{Results from Quantitative Analysis}

The content analysis of 62 units of the data is presented in Table 3.

Table 4.1

Distribution of cultural specific texts in the four textbooks

\begin{tabular}{lccc}
\hline \multicolumn{1}{c}{ Province } & $\begin{array}{c}\text { Total number of } \\
\text { lessons }\end{array}$ & $\begin{array}{c}\text { Cultural-specific } \\
\text { texts }\end{array}$ & Percentage \\
\hline Punjab & 11 & 9 & $81 \%$ \\
Khyber Pakhtunkhwa & 18 & 16 & $88 \%$ \\
Sindh & 19 & 13 & $68 \%$ \\
Baluchistan & 14 & 10 & $71 \%$ \\
Total & 62 & 48 & $77 \%$ \\
\hline
\end{tabular}


The table illustrates higher frequency of cultural texts in KP and Punjab. The content distribution into general categories (defined in Table 4.1) is provided below;

Table 4.2

Comparison of Cultural categories in the four books

\begin{tabular}{llllll}
\hline Textbooks & Religious & National & Regional & International & Free \\
\hline Punjab & $18 \%$ & $27 \%$ & - & $36 \%$ & $18 \%$ \\
KPK & $22 \%$ & $44 \%$ & $11 \%$ & $11 \%$ & $11 \%$ \\
Sindh & - & $21 \%$ & $31 \%$ & $26 \%$ & $21 \%$ \\
Baluchistan & $28 \%$ & $28 \%$ & $7 \%$ & $21 \%$ & $14 \%$ \\
\hline
\end{tabular}

The category wise comparison shows higher percentage of target culture $(36 \%)$ in Punjab textbook, with no representation of regional culture. In KP, national culture dominates (44\%), followed by religion (22\%). Sindh Textbook reflects prevalence of regional culture (31\%) but is silent on religion. Baluchistan equally represents religious and national culture (28\%) but undermines regional culture (7\%). Further details according to the sub-categories (defined in Table 2) are presented in Table 5 .

Table 4.3

\section{Cultural representations by Sub-categories}

\begin{tabular}{lccccccccc}
\hline Books & \multicolumn{10}{c}{ Sub-categories } \\
\cline { 2 - 9 } & BE & C \& V & P \& V & ACT & SCI & EDU & TR & GEO & NR \\
Punjab & 1 & 4 & 1 & 2 & 2 & - & 1 & - & - \\
KP & 3 & 4 & 2 & 3 & 3 & 1 & - & 2 & 1 \\
Baluchistan & 3 & 4 & 1 & 2 & - & 1 & 2 & 1 & - \\
Sindh & - & 9 & 2 & 5 & - & 1 & 2 & - & - \\
Total & 7 & 21 & 6 & 12 & 5 & 3 & 5 & 3 & 1 \\
$\%$ & 11.2 & 33.8 & 9.6 & 19.3 & 8.06 & 4.8 & 8.6 & 4.8 & 1.6 \\
\hline
\end{tabular}

Among 62 texts, 19 texts are on social and cultural festivals and values, 7 on religious beliefs, 6 on national heroes and achievements, 5 on science and technology, 3 on education, 5 on role of teacher in classroom, 3 on geographic information while 1 is on natural resources. The 48 cultural messages about four cultures are disproportionately distributed, revealing degrees of importance attached to different national cultures and their cultural aspects (Ping, 2011).

\subsection{Results from Qualitative Analysis}

A further examination through discourse analysis uncovers rhetorical strategies used to serve certain ideological purposes. 


\subsubsection{Punjab Primary Textbook of English}

Text 1

On returning to Pakistan, Arfa was given a very warm welcome.

(Line 5, p. 17)

[She] represented Pakistan at various international forum

[being] the only Pakistani in that conference. (Line 10, p. 18)

Arfa Karim as presented above is the symbol of women emancipation and national pride, as a challenge to dominant patriarchal structures of Pakistani society (Syed, Tabassum \& Afzal, 2015; Yousaf, Adnan \& Aksar, 2017) where a woman is expected to be docile (Ahmed, 2009).

Text 2

Little deeds of kindness

Little words of love

Make our earth on Eden

Like the heaven above (Line 9, p. 24)

This stanza (Little Things by Julia A. Carney) is an allegory (a moral lesson of virtue) where 'Eden' symbolizes kindness or love as well as punishment. Since language could be used to magnify things in different ways (Gee, 2014), the target instead of local culture is used to convey love and kindness, which seems inadequate due to regional and religious divide.

Text 3

The first lenses were used in glasses to help people see better.

Then in 1609, ... Galileo ... could see things in the solar system

that no one had ever seen before. (Line 3, p. 43)

In 1675, ... Leeuwenhoek ... made an instrument called a microscope [to] ... see tiny creatures swimming about in a drop of water. (Line 6, p. 43)

The books serve as the basic tool to enhance mental, social, cultural and scientific growth of the learners (Kemp, 1977). This text fails to serve Pakistani culture as it indirectly hints at its inefficiency in science and technology by highlighting scientific achievement of the west.

\subsubsection{My English Reader (KPK)}

Text 4

The Quaid-e-Azam was a true Muslim. He won a free state for us where we live freely. We should act upon his motto, "Unity, Faith Discipline". (Line 14, p. 45)

This text states the characteristics of a good leader to be true, honest and a man of principles, through portrayal of Quaid-e-Azam and provides a contrast 
to the leaders of today's Pakistan. This discourse is inciting the feelings of patriotism and unity among the learners.

Text 5

Many people think education is not necessary for women, but they are wrong. Education for all is the motto of the modern world. (Line 3, p. 94)

Our Holy Prophet said, "Seeking of knowledge is obligatory for every Muslim”. (Line 11, p. 94)

Foucault (1980) postulates knowledge as a powerful weapon against exercise of power. In KP where women education is a challenge, the texts portray women emancipation and modernity as a counter to existing social practices through the more acceptable tool of religion.

Text 6

Takht-i-Bhai is a plain and fertile area. Sugarcane, wheat, maize and tobacco are its main crops. It is famous for delicious 'chapli kababs'. (Line 17, p. 101)

The discourse through the presentation of Takht-i-Bhai (architectural site in KP), crops and local cuisine is in alignment with the source culture's dominant customs and values (Weninger \& Kiss, 2013). The scope of tourism in Pakistan is also hinted at by highlighting its historical glory.

Text 7

In the world of sports, Pakistan and cricket have become integral. ... In cricket, Shahid Afridi is one of the greatest Pakistani all-rounders. (Line 1, p. 111)

A complete unit on cricket serves the purpose of national glorification. Shahid Afridi is depicted as a pride of Afridi tribe and an emblem of Pashtun culture (being fierce and bold).

\subsubsection{English Language Grade 5 (Baluchistan)}

Text 8

Their neighbor explained her point of view, "Education is our religious obligation" .... not only to get the job, but also to improve the ways of life. (Line 6, p. 50)

The women education is represented as a 'religious obligation' which posits a paradox to the existing discursive practices. It at the same time propagates the ideology of male chauvinism by hinting that the destiny of women is in the hands of males as they can only get education with their permission. Text 9

Arfa Karim is the pride of Pakistan became Microsoft certified professional at the age of nine. (Line 8, p. 65) 
Zainab Imran bears the honor of representing Pakistan in

London Olympics at the age of sixteen. (Line 1, p. 67)

The unit has listed achievements of seven people (two females and five males), but the symbolic values are attached more with the female figures of Arfa Karim and Zainab Imran especially of women emancipation against provincial particularly.

Text 10

Teacher: Dear students, Mehargarh was discovered in 1974.

This place contains the remains an early civilization .... (Line 3, p. 91)

Mehargarh, the oldest civilization of the region, is represented to promote tourism and glorify Balochistan. It also draws attention of the regional and national government towards the crumbling state of tourist sites.

\subsubsection{My English book (Sindh)}

Text 11

Zeenat: hello, Seema! What are you doing?

Seema: I'm helping my mother in making a rillee. (Line 1, p. 9)

Rillee, a patchwork art, is presented as a symbol of rich Sindhi traditions, customs, lifestyle, folklore and language, and also a means to transfer these values and norms to the young generation.

Text 12

But there was no middle school for the girls. (Line 8, p. 40)

However, the villagers did not like Zahra going to the boy's school.

They said, "Zahra must stay at home with her mother."(Line 37, p. 41)

These phrases describe the story of a girl Zahra, chained in social patriarchal norms of Sindhi rural setup. On her initiative of joining boys' school, her treatment by villagers as a loathsome creature expresses resistance of women emancipation.

\section{Findings}

Overall, the cultural specific content in the four books is $77 \%$ while the highest representation is found in KP and Punjab textbooks (above 80\%). Category wise content analysis reflects higher percentage of target culture in Punjab with no presentation of regional culture. In KP and Baluchistan, national and religious cultures dominate, whereas Sindh gives greater emphasis to the regional culture. The following section summarizes the findings of both quantitative and qualitative analysis. 


\subsection{Punjab}

The qualitative analysis revealed representation of women as a symbol of pride and role model against male chauvinistic norms (Yousaf, Adnan \& Aksar, 2017). However, the domination of western thought is prevalent through the use of biblical images for expression of peace and love. Therefore, international culture is used for creating harmony and prosperity among the local cultures.

\subsection{KP}

In contrast, KP textbook promotes social harmony through a local role model as reflected through examples of local/national heroes, culture and history. Women education is favored through the use of religion as a tool.

\subsection{Baluchistan}

Similar to KP, Baluchistan textbook also glorified regional culture and civilization, along with the presentation of women as role models, but a stronghold of religion over propagated ideologies is visible.

\subsection{Sindh}

Sindhi regional cultural is represented in a high esteem. The need for women education is highlighted in a way that reflects stronghold of patriarchal values in the social setup.

\section{Discussion}

The analysis uncovers the ideological nature of culture specific contents in the four books. The cultural representations are not balanced and reflect dominant ideologies.

Punjab, closer to the center, is found to embody federal government policies. The national ideology is affected by messages of inventions, moral lessons of kindness, mercy or love from the target culture, and negligible representation of eastern and Islamic ideologies, hinting at western vested interests of the dominant groups. The National Bureau of Curriculum and Textbooks (NBTC) seems incapable of creating national integrity between the provincial boards as reflected through stronghold of western ideologies in the textbook. The situation is different in the provinces where the hold of the center is less pronounced. KP and Baluchistan textbooks are successful in a way to provide local/national role models as reflected through propagation of local, religious and cultural ideologies instead of the target culture. The book of KP province as an embodiment of regional and national culture seems to be in alignment with NBTC's motto. This is achieved though messages on the national hero, national achievements, Pashtun, valor, cuisine, geographical significance and more importantly messages on women education. 
The dominance of religion in the provinces of KP and Baluchistan is reflected through their use of religion to legitimize the need for female education and emancipation. Baluchistan textbook also contains some challenging discourse, as here representations of women are made from the point of view of a patriarchal male, instead of reflecting female point of view from their stand point. On the similar issue, the discourse of disagreement on women education in Sindhi textbook points to the resistance mafia against these emancipatory moves. The absence of religious culture from Sindhi textbook points to the sensitivity attached to religion in the province and thus avoidance of the topic by curriculum developers.

The inequality in ideological representations of cultures posits a conflict in NBCT policy which aims to create harmony and enhance national ideology in provincial textbook boards. In this regard, Rehman $(1995 ; 2003)$ delineates that, "language becomes an identity symbol under modern conditions when different collectivities compete for power and resources". The possibility of increased communication facilitates the manipulation of larger labels for group identities such as religion or language. These labels supersede, or push into the background, such pre-modern and smaller labels as kinship, tribal, class and occupational labels or markers of identity. Thus, while pre-modern Siraikis of South Punjab saw themselves as Multanis, Riasatis (inhabitants of the state of Bahawalpur) and so on, the term Siraiki is used for the whole collectivity now. Hence, the textbooks specifically language textbooks are used in Pakistan as a tool to communicate ideological messages to the students (Rehman, 2002) where propagation of some ideologies are favored over the others.

\section{Conclusion}

The results clearly show that textbooks are not written by a single body but a product of the autonomous textbook boards. There is a clear cut disproportion of cultural messages as each book represents the dominant ideologies of its province which posits differing effects on the ideologies of the learners. Textbooks are the mirror for the students through which they see Pakistani culture, society and the dominant ideology.

The varying ratios of cultural representations point towards differing beliefs and opinions which somehow are unable to foster national harmony and reduce provincial tensions and grudges. Although NBTC aims to create a balanced representation, discerning regional concerns are articulated in different ways in these educational materials. In this regard, the textbook boards of each province are responsible for developing the books under the guidelines of national curriculum. A matter of great concern in this regard is the use of western role models for creating motivation in the local youth. This is in direct clash with 
the ideal of national harmony and serves neocolonial agenda/interests. In this regard, KP (and to an extent Baluchistan) textbook presents a better working model to maintain this balance. A lot is still to be desired. Although women education is projected as a regional and national priority, this is not done through the voices of women. The projection of such ideologies from a patriarchal lens places a big question mark on the purpose of such discourses.

\section{Recommendations}

In the light of the findings, this study questions the concept of equal representation of ideologies in the primary level English textbooks. If the ultimate purpose of a curriculum is to fulfil the needs of the local youth, the type of ideologies reflected in the textbooks highlight the need to carry out some work towards policy making.

A thorough educational policy, documenting cultural representation, without serving the vested interests of the powerful elites is required. The effects of such ideologies are far-fetched and should be a matter of concern for policy makers. Bringing in the dissenting voices and marginalized groups in the provincial textbooks (such as female gender) is the need of the day. Great care in this regard is to be taken to counter misrepresentation of some cultures; otherwise such efforts can easily amount to further strengthening the power groups and their hidden cause.

Therefore, this study strongly recommends a revisit by policy makers of the ideals and definitions of nationalism, female emancipation and role of academia in addressing local as well as international concerns. This research is limited to the primary level textbooks. Further research in the domain at other levels can be carried out for addressing the concerns of the indigenous culture and context.

\section{References}

Abdullah, N. (2009). Cultural Elements in a Malaysian English Language Textbook. [Online]. Available at ddms.usim.edu.my/bitstream/handle [10 September 2019]

Adaskou, K., Britten, D., \& Fahsi, B. (1990). Design decisions on the cultural content of a secondary English course for Mororcco. ELT journal, 44(1), 3-10.

Ahmed, Z. (2009). Pakistani feminist fiction and the empowerment of women. Pakistaniaat. A Journal of Pakistan Studies, 1(2), 90-102.

Apple, M.W. (1996). Culture Politics \& Education. New York: Teachers College Press. 
Apple, M.W. (2004). Ideology \& Curriculum. (3 ${ }^{\text {rd }}$ edition). New York: Routledge.

Ball, S. J., Goodson, I. F., \& Maguire, M. (Eds.). (2007). Education, Globalisation and New Times: 21 Years of the Journal of Education Policy. Routledge.

Beiki, M., \& Gharaguzlu, N. (2017). The Analysis of Iranian English School Text Book: A CDA Study Based on Norman Fairclough's 1989 Model. International Journal of Humanities and Cultural Studies (IJHCS), 4(1), 55-67.

Bourdieu, P. (1977). Outline of a theory of practice. Cambridge: Cambridge University Press.

Corson, D. (Ed.). (1995). Discourse and power in educational organizations. Cresskill, NJ: Hampton Press.

Creswell, J. W. (2016). Research Design: Qualitative, Quantitative and Mixed Methods Approaches ( $4^{\text {th }}$ ed.). Thousand Oaks, CA: Sage.

Dehbozorgi, M., Amalsaleh, E. \& Kafipour, R. (2017). Cultural categories in three mainstream EFL textbooks in Iran: A case study of Top Notch, American English Files and Four Corners! International Journal of Research Studies in Education, 7(3), 93-103.

Fairclough, N. (1996). Language and Power. New York: Longman Inc.

Fairclough, N. (2015). Language and Power ( $3^{\text {rd }}$ edition). Routledge.

Foucault, M. (1998). The history of sexuality: The will to knowledge. London: Penguin

Foucault, M. (1977). Discipline and Punish. New York: Pantheon.

Gee, J. P. (2000). Identity as an analytical lens for research in education. Review of Research in Education, 25(1), 99-125. doi:10.2307/1167322

Gee, J. P. (2014). An introduction to discourse analysis: Theory and method. Routledge.

Halliday, M. (1973). Explorations in the functions of language. London: Edward Arnold. 
Hermawan, B. \& Noerkhasanah, L. (2012). Traces of Culture in English textbooks for primary education. Indonesian Journal of Applied Linguistics, 1(2), 46-61.

Kemp, J. E. (1977). Instructional design: A plan for unit and course development $\left(2^{\text {nd }}\right.$ ed.). New York: Longman.

Kirkgoz, Y. \& Agcam, R. (2011). Exploring Culture in Locally Published English Textbooks for Primary Education in Turkey. C.E.P.S Journal, l(1), 153-167.

Krippendorff, K. (2004). Content Analysis: An Introduction to its methodology. London: Sage Publications.

Lyons, J. (2011). Language and Linguistics: An Introduction. Cambridge: Cambridge University Press.

Ping, Q. (2011). Cultural Representations in Primary English Language textbooks in China (Master's Thesis, National Institute of Education, Nangyang Technological University, Singapore). Retrieved from https://pdfs.semanticscholar.org/bef2/4172830f3c35c0bfbc113f2e185677 58d315.pdf

Pitsoe, V. \& Letseka, M. (2013). Foucault's Discourse and Power: Implications for Instructionist classroom management. Open Journal of Philosophy. $3(1), 53$.

Razmjoo, S. A., \& Jozaghi, Z. (2010). The Representation of multiple intelligences types in the Top-Notch series: A textbook evaluation. Journal of Pan-Pacific Association of Applied Linguistics, 14, 59-84.

Rehman, T. (1995). Language Planning and Politics in Pakistan. Sustainable Development Policy Institute.

Rehman, T. (2003). Language-teaching and Power in Pakistan. National Institute of Pakistan Studies \& Summer Institute of Linguistics.

Rogers, R., Malancharuvil-Berkes, E., Mosley, M., Hui, D., \& Joseph, G. O. G. (2005). Critical discourse analysis in education: A review of the literature. Review of Educational Research, 75(3), 365-416. doi:10.3102/00346543075003365

Simpson, P., \& Mayr, A. (2013). Language and power: A resource book for students. Routledge. 
Stevens, E. Y. (2016). Teacher Discourses and Identities: Understanding Your Teaching Self. Retrieved from https://milnepublishing.geneseo.edu/stepsto-success/chapter/14-teacher-discourses-and-identities-understandingyour-teaching-self/

Su, Y. (2007). Ideological Representations of Taiwan's history: An analysis of elementary social studies textbooks, 1978-1995. Curriculum Inquiry, 37(3), 205-237.

Suemasa, M. (2004). "Middle School ELT as a Vehicle for Intercultural Education in Japan: An Evaluation of Textbooks". Global English and Primary Schools: challenges for elementary education. Melbourne: CAE Press.

Syed, N. T., Tabassum, H., \& Afzal, T. (2015). Women's representation in national assembly of Pakistan. Grassroots, 49(1),

Van Dijk, T. A. (2001). Critical Discourse Analysis: The handbook of discourse analysis. Blackwell Publishers.

Weninger, C., \& KISS, T. (2013). Culture in English as a Foreign Language (EFL) Textbooks: A Semiotic Approach. TESOL Quarterly, Retrieved from http://www.jstor.org/stable/43267925

Wodak, R. (2002). Aspects of critical discourse analysis. Zeitschrift für Angewandte Linguistik, 36(10), 5-31.

You, X. (2005). Ideology, Textbooks and the Rhetoric of Production in China. College Composition and Communication (CCC), 56(4), 632-653.

Yousaf, Z., Adnan, M., \& Aksar, I. A. (2017). Challenges of Patriarchal Ideologies in Pakistani Cinema: A Case of Feminist Depiction in Films. Global Media Journal: Pakistan Edition, 10(1), 1-21.

\section{Citation of this Article:}

Dar, S., \& Masroor, F. (2019). Cultural Dissemination: A Case Study of English Text Books at Primary Level in Pakistan. International Journal of Innovation in Teaching and Learning (IJITL), 5(2), 33-48. 